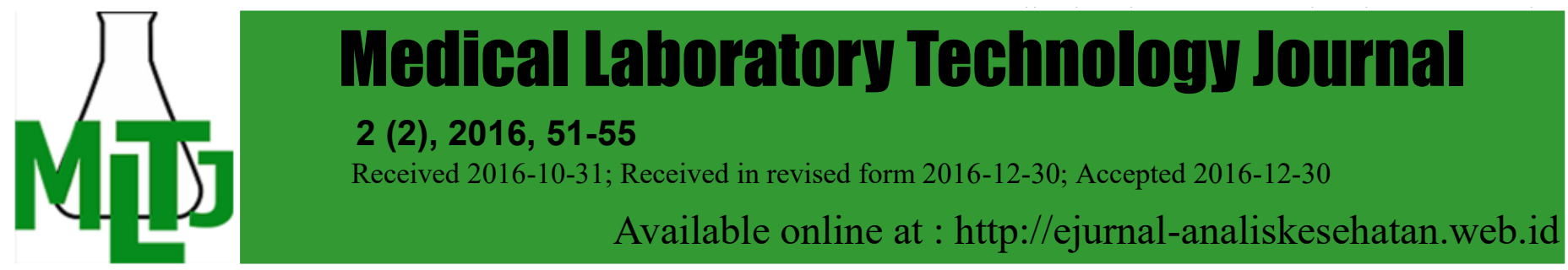

\title{
KANDUNGAN ASAM OKSALAT SAYUR BAYAM
}

\author{
Herlena Fitriani, Nurlailah, Dinna Rakhmina \\ Jurusan Analis Kesehatan Poltekkes Kemenkes Banjarmasin \\ JI Mistar Cokrokusumo 4a Banjarbaru \\ e-mail: dinnapoltekesbjm@gmail.com
}

\begin{abstract}
Spinach is one of vegetable that is often used as processed food by the people of Indonesia. Besides containing many nutrients, spinach also contains chemical compounds that are negative, that is oxalic acid. Oxalic acid and its salts are water soluble that can be harmful because these compounds are toxic. This study aimed to determine differences in levels of oxalic acid in spinach when the water is allowed to stand at room temperature. The type of research was pre-experiment with one group pretest-posttest design. Samples of spinach water were divided into 4 treatment and the level of oxalic acid was examined by using permanganometry titration method. Results of research on each treatment showed oxalic acid levels on 0 hour standing was $3753.2 \mathrm{mg} / \mathrm{L}$, 2 hours standing was $3980.0 \mathrm{mg} / \mathrm{L}$, 4 hours standing was $4066.5 \mathrm{mg} / \mathrm{L}$, and the 6 hours standing was $4254.5 \mathrm{mg} / \mathrm{L}$. Repeated ANOVA statistical test results stated there were significant differences in the levels of oxalic acid in spinach water between 0 hour standing and room temperature-standing with a significance value of $p<0.05$. It is concluded that there are significant differences in the levels of oxalic acid in spinach water between 0 hour standing and room temperature-standing. It is advisable to continue the research by comparing the levels of oxalic acid in spinach with different types, such as green spinach, white spinach, and red spinach.
\end{abstract}

Keywords: Spinach; Oxalic acid

\begin{abstract}
Abstrak: Bayam merupakan salah satu sayuran yang sering dijadikan olahan makanan oleh masyarakat Indonesia. Selain mengandung banyak nutrisi, bayam juga mengandung senyawa kimia yang bersifat negatif, yaitu asam oksalat. Asam oksalat dan garamnya yang larut air dapat membahayakan karena senyawa tersebut bersifat toksik. Penelitian ini bertujuan untuk mengetahui perbedaan kadar asam oksalat pada air sayur bayam sewaktu dengan yang didiamkan pada suhu ruang. Jenis penelitian praeksperimen dengan rancangan One Group Pretest-Posttest. Sampel penelitian adalah air sayur bayam yang dibagi menjadi 4 perlakuan, diperiksa kadar asam oksalatnya dengan metode titrasi permanganometri. Hasil penelitian pada setiap perlakuan didapatkan kadar asam oksalat yaitu pada pendiaman 0 jam 3753,2 mg/l, pendiaman 2 jam 3980,0 mg/l, pendiaman 4 jam 4066,5 mg/l, dan pendiaman 6 jam 4254,5 mg/l. Hasil uji statistik Repeated Anova menyatakan ada perbedaan bermakna kadar asam oksalat pada air sayur bayam sewaku dengan yang didiamkan pada suhu ruang dengan nilai signifikansi $p<0,05$. Kesimpulan penelitian ini adalah terdapat perbedaan bermakna kadar asam oksalat pada air sayur bayam sewaku dengan yang didiamkan pada suhu ruang. Disarankan untuk melanjutkan penelitian dengan membandingkan kadar asam oksalat pada sayur bayam dengan jenis yang berbeda, seperti bayam hijau, bayam putih, dan bayam merah.
\end{abstract}

Kata kunci: Sayur Bayam; Asam Oksalat 


\section{PENDAHULUAN}

Masyarakat Indonesia memiliki beraneka ragam makanan khas. Kebanyakan makanan yang beraneka ragam tersebut menggunakan sayuran sebagai pendamping makanan pokok untuk memenuhi kebutuhan makanan 4 sehat 5 sempurna. Salah satu jenis sayur yang sering dijadikan olahan makanan adalah sayur bayam (Firdaus, 2014).

Bayam mengandung berbagai nutrisi yang dibutuhkan oleh tubuh. Bayam mengandung vitamin $A, B, C, E$, dan $K$, zat besi, mangan, fosfor, seng, protein, purin, lemak, karbohidrat, flavonoid, amarantin, kalium, selenium, niacin, beta karoten, asam lemak omega3 , serat, neoxathin, violaxanthin, lutein, zeaxanthin, angiotensin, dan antioksidan (Nuraini, 2014).

Selain sebagai sayuran yang mengandung banyak nutrisi, bayam juga dapat dimanfaatkan untuk memperbaiki sistem pencernaan, menurunkan risiko kanker, anti diabetes, berpotensi menurunkan kadar kolesterol, membersihkan darah sehabis bersalin, memperkuat akar rambut, mengatasi kurang darah (anemia), dan gagal ginjal. Selain itu, bayam juga baik untuk mengatasi penyakit kuning, sembelit, dan mencegah penyakit jantung (Nuraini, 2014).

Menurut Pertiwi dan Ginting (2007) sayur bayam sering digunakan dalam olahan sayur bening oleh para ibu rumah tangga karena bayam dapat meningkatkan minat anakanak dalam mengonsumsi sayur. Namun perlu dicermati sayur bayam sebaiknya tidak dipanaskan ulang atau didiamkan dalam waktu lama (lebih dari lima jam) karena zat-zat yang ada dalam bayam bisa berubah menjadi zat beracun, seperti nitrat dan zat besi (Girsang, 2011).

Menurut hasil penelitian yang dilakukan oleh Firdaus (2014) pada sayur bening yang didiamkan 7 jam menunjukkan peningkatan kadar nitrit (nitrat yang teroksidasi oleh udara) sebanyak 4,4400 ppm yang melebihi baku mutu menurut WHO yaitu sebesarr 3,7 ppm. Selain mengandung nitrat yang dapat teroksidasi menjadi nitrit, bayam juga mengandung senyawa kimia yang bersifat negatif, yaitu asam oksalat (Suyanti, 2008). Kandungan asam oksalat akan bertambah atau semakin banyak larut apabila dipanaskan kembali atau dibiarkan terlalu lama (Suwardi, 2011).

Asam oksalat dan garamnya yang larut air dapat membahayakan, karena senyawa tersebut bersifat toksik. Kadar asam oksalat yang tinggi dapat menyebabkan kematian dengan gejala pada pencernaan (abdominal kram dan muntah-muntah) yang cepat diikuti kegagalan peredaran darah dan pecahnya pembuluh darah (Andiani, 2009). Selain bersifat toksik, kandungan oksalat yang terlalu tinggi pada makanan dapat mengganggu fungsi ginjal. Di dalam tubuh, oksalat akan bersenyawa dengan kalsium membentuk kristal kalsium oksalat. Kristal tersebut akan mengendap dan jika terkumpul akan membesar membentuk batu ginjal (Lingga, 2010).

Menurut Sentra Informasi Keracunan Nasional dan Badan POM RI (2012) rata-rata dosis letal asam oksalat pada manusia dewasa adalah 15-30 gram. Dosis letal terendah yang pernah dilaporkan adalah 6-8 gram (setelah mengonsumsi sup sorrel). Penelitian ini bertujuan untuk mengetahui perbedaan kadar asam oksalat pada air sayur bayam sewaktu dengan yang didiamkan pada suhu ruang.

\section{BAHAN DAN METODE}

Jenis penelitian ini merupakan penelitian praeksperimen. Rancangan penelitian ini adalah One Group PretestPosttest, Sampel dalam penelitian ini adalah air sayur bayam yang kemudian diperiksa kadar asam oksalatnya. Sampel dibagi menjadi 4 perlakuan yaitu dengan lama pendiaman 0 jam, 2 jam, 4 jam, dan 6 jam dengan 6 kali pengulangan pada masing -masing perlakuan. Penelitian ini dilaksanakan pada 6 Mei 2016 di Laboratorium Kimia Dasar Jurusan Analis Kesehatan Politeknik Kesehatan Kemenkes Banjarma$\sin$.

Variabel terikat dalam penelitian ini adalah kadar asam oksalat pada air sayur bayam. Variabel bebas dalam penelitian ini adalah lama pendiaman sayur bayam yaitu 0 jam, 2 jam, 4 jam, dan 6 jam.

Data primer yaitu data diperoleh dengan cara pemeriksaan kadar asam oksalat pada air sayur bayam sebelum dan sesudah perlakuan. Persiapan Sampel yaitu bayam yang sudah diidentifikasi jenisnya diambil bagian daunnya. Daun bayam dicuci dengan aquadest dengan satu kali pencucian. Aquadest sebanyak $400 \mathrm{ml}$ dimasukkan ke dalam gelas piala, dipanaskan di atas hot plate sampai mendidih. Setelah mendidih, dimasukkan $40 \mathrm{gr}$ daun bayam, diaduk. Biarkan sampai matang (3,5 menit setelah daun bayam dimasukkan). Sayur bayam diangkat dari hot plate. 
Didinginkan 15 menit, diambil airnya sebagai sampel air sayur bayam sewaktu (0 jam) dan dititrasi secara permanganometri untuk menentukan kadarnya. Kemudian air sayur bayam diambil kembali 2 jam, 4 jam, dan 6 jam setelah sayur didiamkan pada suhu ruang dan dititrasi secara permanganometri. Dilakukan 6 kali pengulangan setiap perlakuan.

Standarisasi larutan $\mathrm{KMnO}_{4} \quad 0,01 \mathrm{~N}$ dengan larutan $\mathrm{H}_{2} \mathrm{C}_{2} \mathrm{O}_{4} 0,01 \mathrm{~N}$. Penetapan Kadar dilakukan dengan cara diambil air sayur bayam masing-masing $2,5 \mathrm{ml}$ pada setiap pemeriksaan, dimasukkan ke dalam labu ukur $100 \mathrm{ml}$. Ditambahkan aquadest sampai tepat tanda batas, kocok bolak-balik. Air sayur bayam yang sudah diencerkan dipindahkan ke dalam erlenmayer. Ditambah larutan baku $\mathrm{KMnO}_{4}$ 0,01 N sampai merah muda. Ditambah $5 \mathrm{ml} \mathrm{H}_{2} \mathrm{SO}_{4} 4 \mathrm{~N}$. Dimasukkan batu didih, dipanaskan sampai mendidih 1 menit. Ditambah $30,0 \mathrm{ml}$ larutan baku $\mathrm{KMnO}_{4} 0,01 \mathrm{~N}$. Dipanaskan sampai mendidih 10 menit (warna larutan tidak hilang/konstan). Ditambah 10,0 ml larutan baku $\mathrm{H}_{2} \mathrm{C}_{2} \mathrm{O}_{4} 0,01 \mathrm{~N}$ (warna larutan menjadi bening). Dititrasi dengan larutan baku $\mathrm{KMnO}_{4}$ 0,01 $\mathrm{N}$ sampai terbentuk warna merah muda konstan. Dilakukan 6 kali pengulangan setiap perlakuan.

\section{HASIL DAN PEMBAHASAN}

Hasil pemeriksaan kadar asam oksalat pada air sayur bayam 0 jam, 2 jam, 4 jam, dan 6 jam dapat dilihat pada tabel 1.

Tabel 1 Hasil Pemeriksaan Kadar Asam Oksalat pada Air Sayur Bayam Berdasarkan Variasi Lama Pendiaman

\begin{tabular}{ccccc}
\hline \multirow{2}{*}{ Pengulangan } & \multicolumn{4}{c}{$\begin{array}{c}\text { Kadar Asam Oksalat Berdasarkan } \\
\text { Variasi Lama Pendiaman (mg/l) }\end{array}$} \\
\cline { 2 - 5 } & 0 jam & 2 jam & 4 jam & 6 jam \\
\cline { 2 - 5 } 1 & 3529,5 & 3994,9 & 4066,5 & 4263,4 \\
2 & 3798,0 & 3977,0 & 4048,6 & 4227,6 \\
3 & 3601,1 & 3994,9 & 4102,3 & 4245,5 \\
4 & 3923,3 & 3977,0 & 4030,7 & 4245,5 \\
5 & 3815,9 & 3977,0 & 4084,4 & 4281,3 \\
6 & 3851,9 & 3959,1 & 4066,5 & 4263,4 \\
Rata-rata & 3753,2 & 3980,0 & 4066,5 & 4254,5 \\
\hline
\end{tabular}

Peningkatan kadar asam oksalat dalam air sayur bayam dapat dilihat pada gambar 1 .

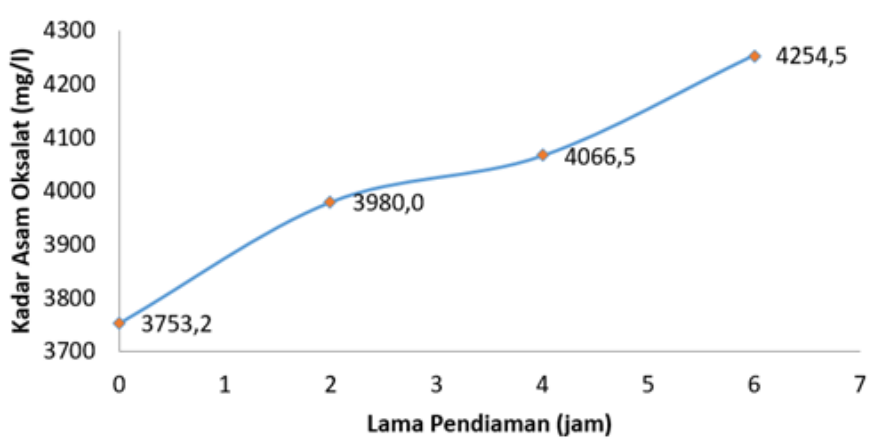

Gambar 1 Grafik Peningkatan Kadar Asam Oksalat dalam Air Sayur Bayam

Persentase peningkatan kadar asam oksalat dapat dilihat pada gambar 2 .

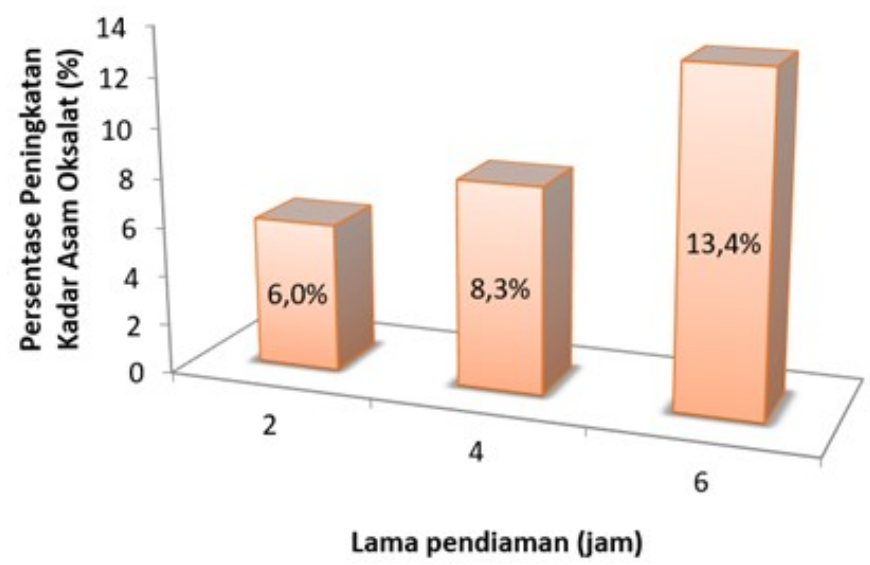

Gambar 2 Persentase Peningkatan Kadar Asam Oksalat

Hasil uji normalitas data dengan menggunakan uji Shapiro-Wilk, diperoleh nilai signifikansi kadar asam oksalat pendiaman 0 jam, 2 jam, 4 jam, dan 6 jam masingmasing sebesar 0,361, 0,173, 0960, dan $0,820(p>0,05)$ yang artinya semua data berdistribusi normal.

Berdasarkan hasil uji Repeated Anova yaitu ada perbedaan bermakna kadar asam oksalat air sayur bayam pada lama pendiaman 0, 2, 4 dan 6 jam dengan nilai signifikansi $0,001(p<0,05)$. Uji lanjut dengan LSD diperoleh hasil pada semua perlakuan nilai signifikansi kurang dari $0,05(p<0,05)$ yang berarti ada perbedaan bermakna kadar asam oksalat air sayur bayam pada tiap perlakuan.

Berdasarkan hasil pemeriksaan kadar asam oksalat pada air sayur bayam, lamanya pendiaman sayur bayam pada suhu ruang menyebabkan kadar asam oksalat pada air sayur bayam meningkat. 
Hal ini sesuai dengan penelitian yang dilakukan Suwardi (2011) pada daun bayam yang juga terjadi peningkatan kadar oksalat setelah didiamkan selama 5 menit, 1 jam, 2 jam, 3 jam, dan 4 jam dengan hasil masingmasing 24,5653 mg/l, 45,515 mg/l, 74,358 mg/ I, 97,4493 mg/l, dan 110,018 mg/l. Namun hasil kadar oksalat tersebut sangat berbeda dengan penelitian ini. Pada penelitian ini didapatkan hasil kadar asam oksalat pada pendiaman 0 jam, 2 jam, 4 jam, dan 6 jam masing-masing sebesar 3753,2 mg/l, 3980,0 $\mathrm{mg} / \mathrm{l}, 4066,5 \mathrm{mg} / \mathrm{l}$, dan 4254,5 mg/l. Perbedaan hasil ini karena jumlah sampel yang digunakan berbeda. Pada penelitian Suwardi (2011) digunakan 2,5 gr daun bayam yang kemudian digerus dan dididihkan menggunakan aquadest sebanyak $250 \mathrm{ml}$, sedangkan dalam penelitian ini digunakan daun bayam sebanyak $40 \mathrm{gr}$ yang dididihkan dalam $400 \mathrm{ml}$ aquadest.

Kadar asam oksalat dalam penelitian ini memang berbeda dengan penelitian sebelumnya, namun keduanya sama-sama mengalami peningkatan jumlah oksalat setelah didiamkan selama beberapa jam. Pada gambar 4.2 dapat dilihat persentase peningkatan kadar asam oksalat dalam penelitian ini. Jumlah peningkatan kadar asam oksalat pada air sayur bayam setelah didiamkan selama 6 jam $(4254,8 \mathrm{mg} / \mathrm{l})$ sebesar $13,4 \%$ dari air sayur bayam sewaktu atau 0 jam (3753,2 mg/l). Peningkatan kadar asam oksalat pada air sayur bayam ini disebabkan oleh pendiaman sayur bayam yang cukup lama. Kandungan asam oksalat akan semakin banyak larut atau bertambah apabila dibiarkan terlalu lama (Suwardi, 2011).

Kadar asam oksalat dalam penelitian ini sangat tinggi, yaitu berkisar antara $3753,2 \mathrm{mg} / \mathrm{l}$ sampai $4254,5 \mathrm{mg} / \mathrm{l}$. Hal ini sesuai dengan penelitian Wanasundera dan Ravindran (1992) yang membuktikan bahwa melalui proses perebusan asam oksalat dalam bayam tereduksi sebanyak 40-50\% (Noonan dan Savage, 1999).

Menurut Sentra Informasi Keracunan Nasional dan Badan POM RI (2012) rata-rata dosis letal asam oksalat pada manusia dewasa adalah 15-30 gram. Dosis letal terendah yang pernah dilaporkan adalah 6-8 gram (setelah mengonsumsi sup sorrel).

Dalam penelitian ini menunjukkan bahwa sayur bayam yang didiamkan sampai 6 jam masih memiliki kandungan asam oksalat di bawah dosis letal. Namun perlu diperhatikan, walaupun kandungan asam oksalat tidak melebihi dosis yang dapat menyebabkan ke- matian, secara statistik dapat dilihat bahwa kandungan asam oksalat pada sayur bayam yang didiamkan selama 2 jam sudah memiliki perbedaan yang bermakna dengan kadar asam oksalat pada air sayur bayam sewaktu dengan nilai signifikansi 0,018 ( $p<0,05)$.

Kandungan asam oksalat yang tinggi di dalam tubuh dapat membahayakan, karena kandungan oksalat yang terlalu tinggi dapat mengganggu fungsi ginjal. Asam oksalat tidak dapat dimetabolisme lebih lanjut pada manusia dan diekskresi melalui urin. Mengomsumsi makanan tinggi oksalat dapat meningkatkan ekskresi oksalat dalam urin. Kenaikan yang mencolok pada ekskresi oksalat urin (ekskresi normal $10-50 \mathrm{mg} / 24$ jam) dapat menyebabkan pembentukan batu ginjal. Terbentuknya batu ginjal ini terjadi karena oksalat bersenyawa dengan kalsium membentuk kristal kalsium oksalat. Kristal kalsium oksalat tidak larut dalam air dan jika kadarnya dalam tubuh naik kristal kalsium oksalat tersebut akan mengendap dalam jaringan membentuk batu yang disebut dengan batu ginjal (Arvin, 2000).

Asam oksalat yang terlalu tinggi, selain dapat memicu terbentuknya batu ginjal juga dapat menghambat penyerapan zat besi. Zat besi merupakan salah satu komponen yang sangat diperlukan oleh tubuh. Kekurangan zat besi dapat menyebabkan seseorang menderita anemia dan gangguan pertumbuhan (Weafer dalam Syarif, Rivai, Fahmi, 2007).

\section{KESIMPULAN}

Bersadarkan hasil uji statistik Repeated Anova, ada perbedaan bermakna kadar asam oksalat pada air sayur bayam sewaktu (0 jam) dengan yang didiamkan pada suhu ruang selama 2 jam, 4 jam, dan 6 jam dengan nilai signifikansi $0,001(p<0,05)$.

\section{SARAN}

Saran penelitian selanjutnya agar membandingkan kadar asam oksalat pada sayur dengan jenis yang berbeda, seperti bayam hijau, bayam putih, dan bayam merah.

\section{DAFTAR PUSTAKA}

Andiani, D. (2009). Pembuatan Asam Oksalat dari Tongkol Jagung dengan Pengaruh Waktu dan Konsentrasi HNO3. Politeknik Negeri Sriwijaya, Palembang.

Arvin, B. K. (2000). Ilmu Kesehatan Anak (15th ed.). Jakarta: EGC.

Firdaus, A. (2014). Perbandingan Kadar Nitrit (NO2-) pada Sayur Bening Sewaktu dengan Didiamkan pada Suhu Ruang. Analis Kesehatan Poltekkes Banjarmasin. 
Girsang, D. (2011). Pengaruh Penambahan Pupuk Urea terhadap Kandungan Nitrit pada Tanaman Bayam (Amaranthus L.) Setelah Dimasak Selama Lima Menit. Universitas Sumatera Utara.

Lingga, L. (2010). Lingga L, 2010. Cerdas Memilih Sayuran, Agro Media Pustaka, Jakarta. Jakarta: Agro Media Pustaka.

Noonan, S. C., \& Savage, G. P. (1999). Oxalate Content of Food and Its Effect on Humans. Lincoln University.

Nuraini, D. N. (2014). Aneka Daun Berkhasiat untuk Obat. Yogyakarta: Penerbit Gava Media.

Pertiwi, A., \& Ginting, A. L. (2007). Yuk, Makan Bayam! Jakarta: Gramedia Pustaka Utama.

Suwardi. (2011). Analisa Kadar Oksalat dalam Daun Bayam yang Sudah Dimasak dengan Metode Spektrofotometri UV. Universitas Islam Negeri Sultan Syarif Kasim Riau.

Suyanti. (2008). Membuat Mie Sehat Bergizi dan Bebas Pengawet. Jakarta: Penebar Swadaya.

Syarif, M., Rivai, H., \& Fahmi, F. (2007). Pemeriksaan Kadar Oksalat dalam Daun Singkong (Manihot utillissima). Universitas Andalas. 